\title{
37. STRATIGRAPHIC RESPONSE OF CARBONATE PLATFORMS AND TERRIGENOUS MARGINS TO RELATIVE SEA-LEVEL CHANGES: ARE THEY REALLY THAT DIFFERENT? ${ }^{1}$
}

\author{
Neal W. Driscoll, ${ }^{2,3}$ Garry D. Karner, ${ }^{2}$ and Jeffrey K. Weissel ${ }^{2}$
}

\begin{abstract}
Using seismic-reflection data and ODP drilling results collected from Broken Ridge we examine the stratigraphic response of a carbonate platform to relative sea-level changes. Interpretation of the seismic-reflection and drilling data indicates the following stratigraphic response of the platform to relative sea-level changes: prograding clinoforms comprising lower Maestrichtian to middle Eocene limestones and chalks were deposited during a long-term relative sea-level rise. High productivity allowed the carbonate sediment to prograde north into the basin during the rise. Onlapping sequences consisting of carbonate detritus were deposited along the northern slope of Broken Ridge in response to the middle Eocene rift-induced relative sea-level fall. The carbonate strata on Broken Ridge were uplifted to at least wave base during middle Eocene time and consequently eroded. The carbonate detritus was transported north into the basin and onlaps the preexisting slope of Broken Ridge.

We propose that the stratigraphic response of Broken Ridge to the middle Eocene relative sea-level fall is consistent with stratigraphic predictions based on terrigenous margins. However, during a relative sea-level rise, biogenic carbonate production may allow carbonate sediment to prograde basinward despite the fact that water depths are increasing. Stratigraphic models based on terrigenous margins do not account for the increase in sediment supply along carbonate margins during a relative sea-level rise and thus require minor modification in order to predict the development of the prograding clinoforms.
\end{abstract}

\section{INTRODUCTION}

Two conflicting stratigraphic models have been developed recently to understand and predict the response of carbonate margins to relative sea-level changes. Model I suggests that the stratigraphic response of carbonate margins is quite different from that of terrigenous margins (Mullins et al., 1988; Schlager, 1988). In fact, it proposes that large amounts of carbonate sediment are shed into the deep sea during highstands of sea level because of the increased carbonate productivity. Biogenic productivity in carbonate environments appears to be most prolific during highstands of sea level. Estimates of Holocene calcareous green algae production in the Bahamas suggest that calcareous sediment production is almost 3 times higher than the portion preserved on bank tops (Neumann and Land, 1975). The excess calcareous sediment is transported into deeper water by downslope processes (Mullins, 1983) and by offbank carbonate sand transport along leeward margins (Hine et al., 1981). Furthermore, Mullins et al. (1988) and Schlager (1988) predicted that during lowstands of sea level there is a paucity of carbonate sediment shed to the deep sea because subaerial exposure causes meteoric cementation and dissolution of the shallow-water carbonate platform (Kendall and Schlager, 1981) and the submerged area of the shallow-water platform available for productivity is diminished.

In the alternative model, the stratigraphic response of carbonate margins to relative sea-level changes is similar to that of terrigenous margins (Vail, 1987; Sarg, 1988). According to this model (Vail, 1987; Sarg, 1988), carbonate sediments should prograde farthest into the basin during relative sea-level falls. Conversely, during a relative sea-level rise sediment is trapped in shallow embayments and on the platform, starving the basins of sediment and resulting in a condensed interval within the basin.

\footnotetext{
'Weissel, J., Peirce, J., Taylor, E., Alt, J., et al., 1991. Proc. ODP, Sci. Results 121: College Station, TX (Ocean Drilling Program).

${ }^{2}$ Lamont-Doherty Geological Observatory of Columbia University, Palisades, NY 10964, U.S.A

${ }^{3}$ Also at the Department of Geological Sciences, Columbia University.
}

The purpose of sequence stratigraphy (Vail, 1987; Van Wagoner et al., 1987) is to define a chronostratigraphic framework and to predict depositional environments from the stratal patterns and acoustic character observed in the seismic-reflection data. The preceding carbonate models predict completely opposite stratigraphic responses to changes in relative sea level. Therefore, it is important to determine which carbonate model is more applicable in order to use sequence stratigraphy as a predictive tool at other carbonate margins.

The predictions of these two alternative models regarding the response of a carbonate margin to relative sea-level changes can be tested. Broken Ridge is an ideal locale in which to use the preserved stratigraphy to test the model predictions for the following reasons: (1) the grid of high-resolution seismic lines $(\approx 20-\mathrm{km}$ spacing) allows mapping of both lateral and downslope sediment thickness and acoustic character variations (Fig. 1) and (2) Ocean Drilling Program (ODP) Leg 121 drilling data allow correlation of the seismic stratigraphy to lithostratigraphy (Fig. 2 ) and also provide estimates of paleodepths from benthic foraminiferal assemblages (Fig. 3; Peirce, Weissel, et al., 1989).

\section{RESULTS}

The technique of seismic sequence analysis (Vail, 1987) was used to interpret the seismic stratigraphy of Broken Ridge (Fig. 1). Five seismic stratigraphic sequences were identified (Figs. 4-7).

\section{Dipping and Truncated Sequence (Sequence I)}

The limestones, cherts, chalks, and tuffs at the crest of Broken Ridge dip uniformly toward the north $\left(\approx 2^{\circ}\right)$ for about $60 \mathrm{~km}$, where the horizons become approximately horizontal. The acoustic reflectors within the sequence are roughly concordant with the underlying reflectors. The acoustic character of Sequence $I$ is discontinuous with a variation in the lateral amplitude of individual reflectors that could result from interspersed diagenetic horizons (i.e., chert horizons; Figs. 4-7).

The Leg 121 Site 755 sampling of the oldest sedimentary section from Broken Ridge revealed that the base of Sequence I is Turonian through middle lower Santonian tuffs with varying 


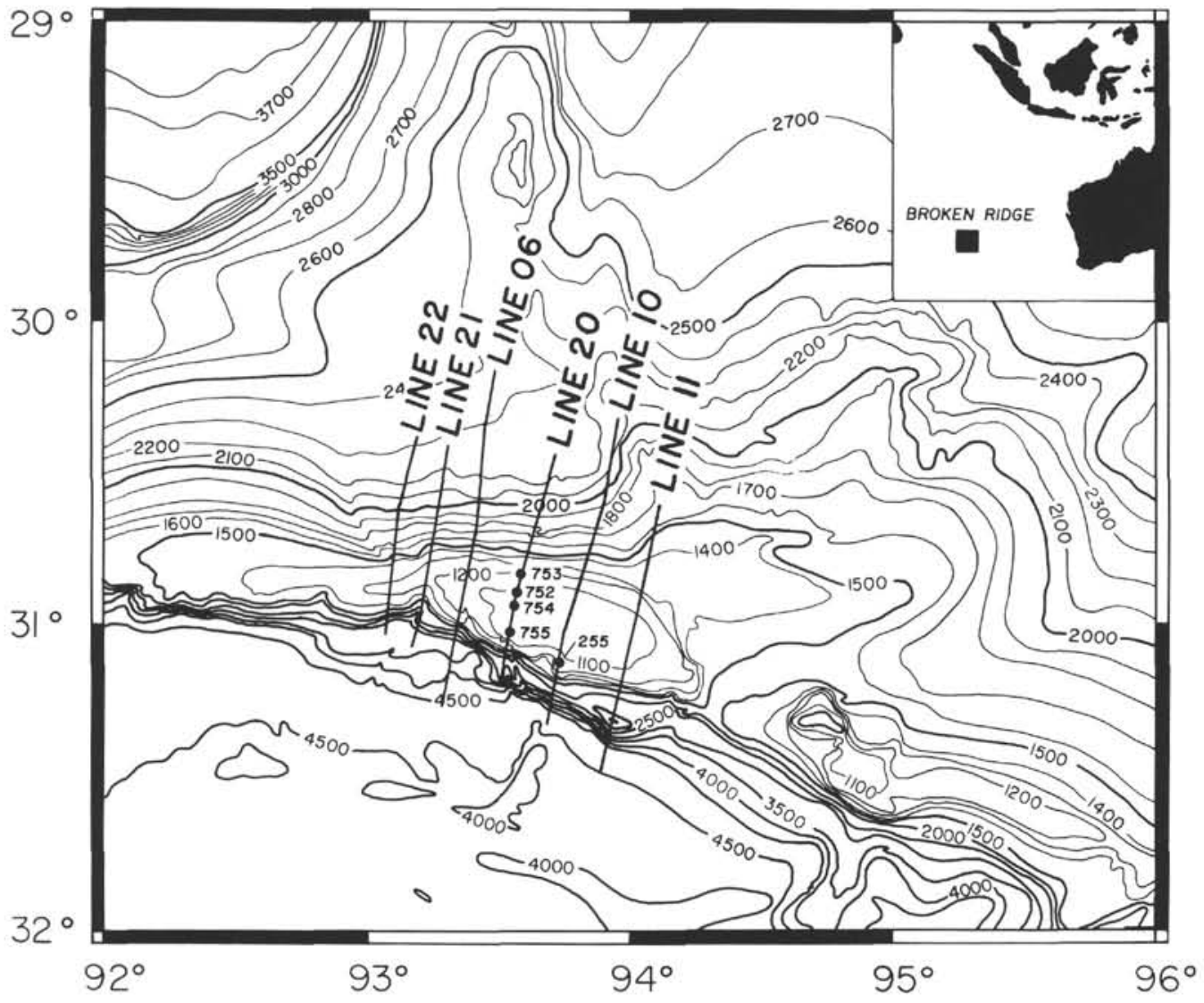

Figure 1. Bathymetry of Broken Ridge, in corrected meters, contoured from precision depth recordings. DSDP Site 255, ODP Sites 752-755, and RC2708 seismic-reflection lines 06, 10,11, 20,21, and 22 are shown. Note that the contour interval drops from 100 to $500 \mathrm{~m}$ toward the south for clarity.

amounts of glauconite and micrite (Fig. 2; Rea et al., 1990). Benthic foraminiferal data indicate upper bathyal to outer neritic depths during the deposition of this sequence (Fig. 3; Peirce, Weissel, et al., 1989).

Deep Sea Drilling Program (DSDP) Site 255 sampled a stratigraphically younger portion of Sequence I and recovered gray fossiliferous biomicritic limestones interspersed with chert layers. The limited amount of material recovered from this sequence falls within the Santonian. Assemblages of planktonic and benthic foraminifers indicate that deposition occurred in an outer shelf environment during the Santonian with depths no greater than a few hundred meters (Davies and Luyendyk, 1974).

\section{Downlapping Sequence (Sequence II)}

Sediment thicknesses for the limestones and chalks composing Sequence II are greatest near the northern edge of Broken Ridge and progressively thin northward away from the ridge (Figs. 4-7; Driscoll et al., 1989). The reflectors observed within Sequence II diverge toward the depocenter and converge basinward, downlapping onto the preexisting strata (Fig. 6). The reflector terminations do not downlap onto one surface (i.e., downlap surface; Van Wagoner et al., 1987) and subtle shifts of downlap are also observed within Sequence II (Fig. 6).

Sequence II consists of the following three distinct acoustic units: (1) a lower weakly laminated unit that exhibits high-amplitude reflectors at the point of onlap onto the preexisting dipping strata, (2) a middle unit with high-amplitude reflectors resulting from ash layers and silica-rich layers interbedded within the nannofossil calcareous chalks, and (3) an upper unit that is acoustically transparent to finely laminated (Fig. 6). The laboratory and downhole-derived acoustic impedance contrasts correlate with these lithologic contacts (Peirce, Weissel, et al., 1989). The ash content of the sediment increases downsection, with a noticeable increase beginning approximately in the upper Paleocene section $(\approx 56-60 \mathrm{Ma}$; Rea et al., 1990). This increase in ash content is roughly coincident with the boundary between the highly reflective middle unit and the acoustically transparent upper unit (Figs. 2 and 6). The ash layers interbedded within the carbonate appear to generate the high acoustic reflectivity of the middle unit within Sequence II (Fig. 4).

Sites 752,753 , and 754 all sampled Sequence II below the angular unconformity (Fig. 2). Site 753 sampled the youngest sediment below the prominent angular unconformity and penetrated approximately $20 \mathrm{~m}$ of middle Eocene ( $\approx 45-50 \mathrm{Ma}$ ) nannofossil chalks with varying amounts of foraminifers. Farther south, at Site 752, a 320-m section of dominantly lower Eocene to middle or upper Maestrichtian nannofossil calcareous chalk was recovered. Finally, at Site 754, approximately $200 \mathrm{~m}$ of lower to upper Maestrichtian limestone and chalk with interspersed ash and chert horizons was recovered.

The benthic foraminiferal assemblages indicate that water depths were increasing during the deposition of Sequence II ( $\approx 75-45$ Ma, Fig. 3; Peirce, Weissel, et al., 1989). The interpreted water depth was approximately upper bathyal at the onset of deposition and increased to middle/lower bathyal depths toward the cessation of deposition for this sequence (Fig. 3). 


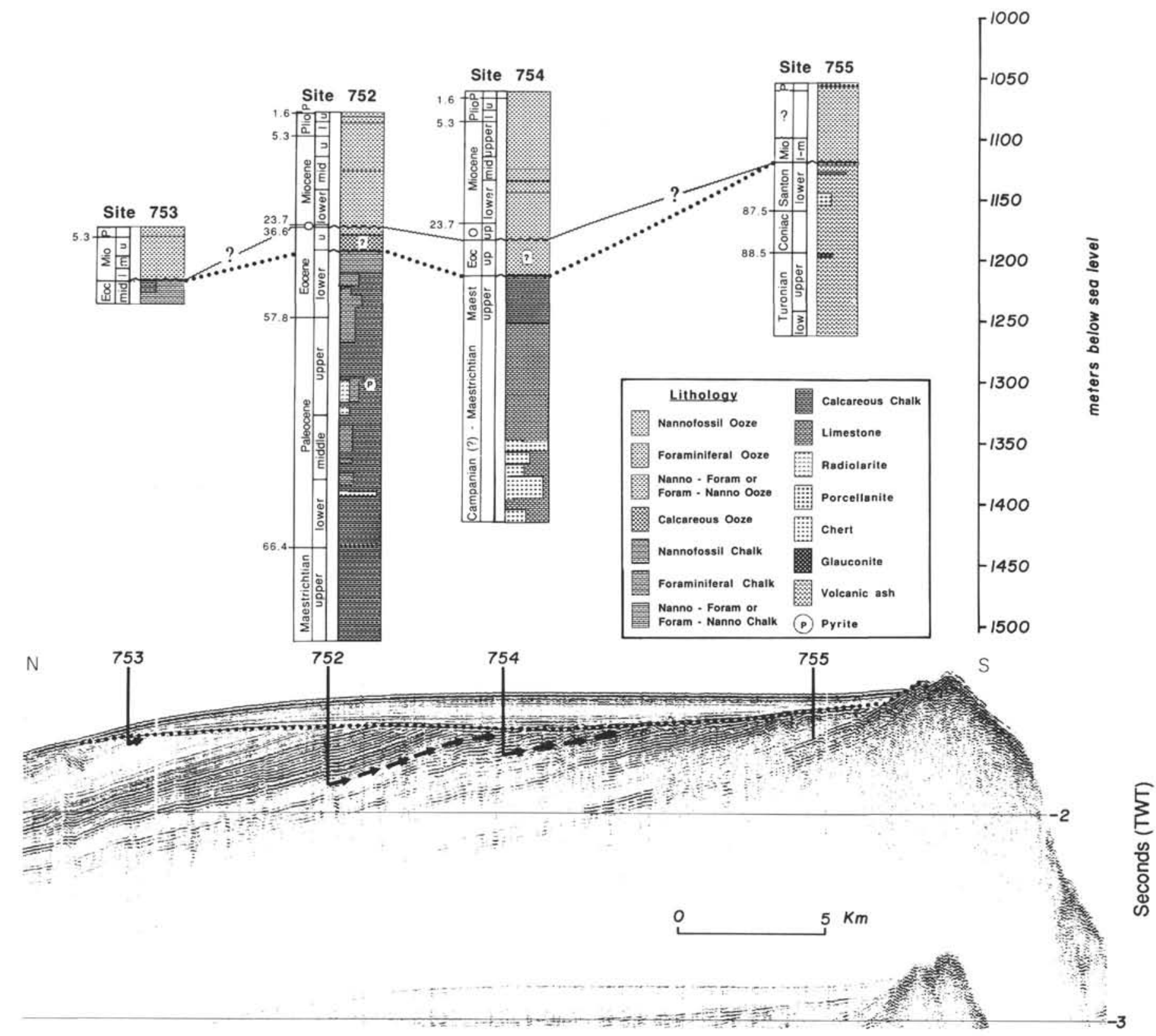

Figure 2. Correlation of lithostratigraphy to seismic stratigraphy at Broken Ridge. The dotted line represents the middle Eocene hiatus and the wavy line represents the Oligocene hiatus. The two hiatuses coalesce at Sites 753 and 755 . However, the question marks indicate that the exact position across Broken Ridge where the hiatuses coalesce is not resolved. The arrows represent the upward continuation of the deepest horizon penetrated at Sites 752, 753, and 754 to illustrate the amount of stratigraphic section recovered and the stratigraphic overlap between sites. 


\section{Broken Ridge Paleodepths}

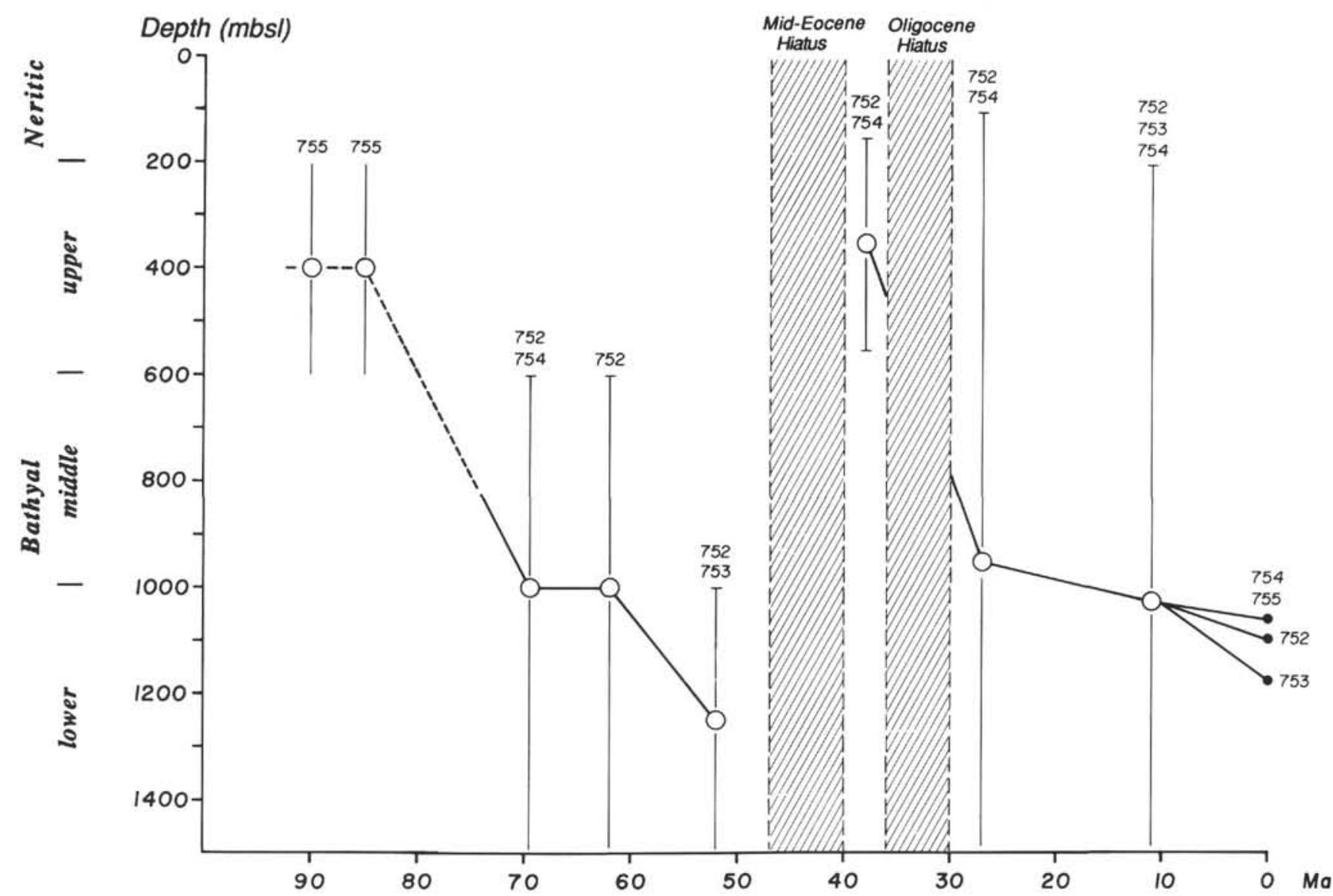

Figure 3. Paleodepth estimates based on assemblages of benthic foraminifers for Sites 752, 753, 754, and 755. An open circle denotes the paleodepth estimate from the most abundant benthic foraminifer present within the sample; a solid circle denotes the present-day depth. The vertical lines represent the range of paleodepth estimates for the entire assemblage of benthic foraminifers present within the sample.

\section{Onlapping Sequence I (Sequence O-I)}

The thickest accumulations of Sequence O-I $(>300 \mathrm{~m})$ infill a preexisting structural low along the northern slope of the ridge toward the west (Fig. 8A; Driscoll et al., 1989). Sequence O-I is truncated and onlapped by a second onlapping sequence ( $\mathrm{Se}$ quence O-II). Sequence O-II appears to be the result of ubiquitous slumping, especially toward the eastern segment, along the northern slope of Broken Ridge (Figs. 4, 5, and 7).

The chaotic internal structure within Sequence O-I, as seen in Figures 5 and 7, may arise from the interaction of many downslope dispersal patterns that overlap and interfinger. The only submarine canyons observed in the study region incise Sequence II and are spatially concentrated along the northern edge of the Broken Ridge crest (Fig. 6). Smaller-scale structures appear to be postdepositional rotational slumps (Figs. 5 and 7).

\section{Onlapping Sequence II (Sequence O-II)}

The $3.5-\mathrm{kHz}$ and water gun seismic records document slump scars along the northern slope of Broken Ridge. The slump scars are restricted to the upper portion of the onlapping sequences (Figs. 4, 5, and 7). The mass flows associated with these slump scars coalesce in the paleo-structural lows and onlap the preexisting sequence (Sequence O-I; Fig. 8B). The finely laminated acoustic character and thickness of Sequence O-II suggest that a multitude of unchannelized mass flows has coalesced to create this sequence (Figs. 5 and 7). The thickest accumulation for Sequence O-II is displaced northward relative to the depocenter for Sequence O-I (Figs. 8A and 8B; Driscoll et al., 1989).

Isopach maps for Sequences O-I and O-II indicate that the volume of sediment onlapping Broken Ridge is approximately equal to the estimated volume of sediment eroded from the crest of Broken Ridge (Fig. 8). The spatial distribution of Sequence O-I encompasses approximately $1^{\circ}$ of longitude and $0.5^{\circ}$ of latitude with an average sediment thickness of $150 \mathrm{~m}$ (Fig. 8A). Given the preceding observations and correcting for the Mercator projection (Snyder, 1926), the volume of sediment for Sequence O-I is $\approx 785$ $\mathrm{km}^{3}$. Sequence O-II has roughly the same spatial dimensions and average sediment thickness as Sequence O-I (Fig. 8B). Therefore, the total volume of sediment of Sequences O-I and O-II is $\approx 1570$ $\mathrm{km}^{3}$. Seismic-reflection and Leg 121 drilling data indicate that the maximum amount of erosion occurred along the southern escarpment of Broken Ridge $(\approx 1300 \mathrm{~m})$ and the amount of erosion diminished northward (Fig. 8D; Peirce, Weissel, et al., 1989). If minimal erosion occurred along the northern edge of the present Broken Ridge crest, then the volume of material eroded from the entire crest of Broken Ridge can be estimated (Figs. 8C and 8D). The spatial distribution of the dipping and truncated sequences is approximately $1^{\circ}$ of longitude and $0.30^{\circ}$ of latitude (Fig. 8C). Therefore, based on the preceding estimates, the volume of sedi- 
ment eroded from the crest of Broken Ridge is $\approx 1390 \mathrm{~km}^{3}$. The approximate agreement between the volume estimates for the eroded material and the onlapping material suggests that small amounts of sediment were removed from the system by chemical erosion.

It is important to note that these volume estimates are not corrected for any porosity differences that might exist between the truncated sequences and the onlapping sequences. This is because only a portion of the truncated sequences and none of the onlapping sequences were sampled during Leg 121 drilling (Fig. 2 ). Despite the fact that there is a negative empirical correlation between compressional-wave velocity and sediment porosity (Nafe and Drake, 1957), the scatter within the data prevents accurate estimates of porosity for a given velocity. However, according to the velocity data this negative empirical correlation implies that, on average, the truncated sequences should have lower porosities than the onlapping sequences (Nafe and Drake, 1957).

\section{Horizontal Cap (Sequence III)}

The horizontal cap rests unconformably on Sequences I and II (Fig. 6). At Site $754, \approx 130 \mathrm{~m}$ of Pleistocene to upper Eocene foraminifer nannofossil ooze was recovered above the prominent angular unconformity (Fig. 2; Peirce, Weissel, et al., 1989). The majority of reflectors within the Neogene cap coincide with changes in the mean grain size of the bulk sediment (Rea et al., 1990).

Two hiatuses have been identified from ODP drilling and seismic-reflection data. The upper hiatus occurs within Sequence III, and the lower hiatus delineates the base of Sequence III. At both Sites 752 and 754 the upper hiatus separates limestone pebbles in an upper Eocene ooze from the overlying upper Oligocene nannofossil ooze. In contrast, at Sites 753 and 755 the hiatus coalesces with a middle Eocene hiatus $(\approx 45 \mathrm{Ma})$, thus increasing the duration of the hiatus at these sites (Fig. 2).

The benthic foraminiferal assemblages indicate that water depths increased prior to the middle Eocene rifting event (Fig. 3). Flexural models for Broken Ridge (Weissel and Karner, 1989) predict more than $2 \mathrm{~km}$ of uplift during the middle Eocene rifting event along the south-facing escarpment and proportionately less uplift farther north. Broken Ridge had subsided to water depths greater than $1000 \mathrm{~m}$ (Fig. 3) at the time of rifting, implying maximum elevation for the south-facing escarpment after uplift of $1000 \mathrm{~m}$. Seismic-reflection and drilling data indicate that $\approx 1300 \mathrm{~m}$ of sediment was eroded from the southern flank of the plateau (Figs. 2 and 8D). These results are consistent with the model predictions of Weissel and Karner (1989). Subsequent to rifting, depths increased rapidly (Fig. 3; Peirce, Weissel, et al., 1989).

\section{INTERPRETATION}

The following depositional model for Broken Ridge represents our interpretation of the high-resolution seismic-reflection and Leg 121 drilling data (Fig. 9):

1. Prior to the Santonian, Broken Ridge/Kerguelen-Heard platform was a shallow-water platform that formed as a consequence of excessive volcanism (hot spot) at or near a spreading center (Morgan, 1981; Peirce, Weissel, et al., 1989). The platform slowly subsided through much of the Late Cretaceous. Terrigenous plant material within the Turonian to middle lower Santonian tuffs suggests that the southern portions of the Broken Ridge/Kerguelen-Heard platform were emergent and vegetated (Site 755; Peirce, Weissel, et al., 1989). The recovery at Sites 748 and 750 , on the southern Kerguelen-Heard Plateau, of Cenomanian and Turonian sediments consisting of glauconitic sands and silts with abundant carbonized wood fragments from land plants also indi- cates that portions of the plateau were subaerially exposed and vegetated (Schlich, Wise, et al., 1989). Sites 755 and 255 on Broken Ridge indicate that carbonate deposition began in the Santonian ("1," Fig. 9).

During the late Campanian, carbonate sediments containing abundant invertebrate faunas (bryozoans, crinoids, inoceramids, siliceous sponges, and coralline red algae) were deposited on the southern Kerguelen-Heard Plateau (Site 748; Schlich, Wise, et al., 1989). The accumulation of these bioclastic carbonates persisted until the late Paleocene.

2. Uplift of the southern Kerguelen-Heard Plateau, which has been dated as early Maestrichtian $(\approx 75 \mathrm{Ma})$, was recorded at Sites 747 and 748 as a hiatus (Schlich, Wise, et al., 1989). Furthermore, Maestrichtian debris flows recovered at Site 747 contained clasts derived from the subaerial erosion of volcanic basement and preexisting strata, suggesting that portions of the plateau were emergent ("2," Fig. 9).

At Site 754 on Broken Ridge, drilling was abandoned just prior to penetrating the sequence boundary between Sequences I and II (Figs. 2 and 6). The drilling data suggest a late Campanian/early Maestrichtian minimum age for the boundary $(\approx 75 \mathrm{Ma}$; time scale of Kent and Gradstein, 1985). The abundant shell fragments (Inoceramus?) observed within the lower Maestrichtian limestones overlying the sequence boundary at Site 754 (Peirce, Weissel, et al., 1989) were probably eroded from the bioclastic carbonates on the southern Kerguelen-Heard Plateau (i.e., Site 748) and transported northward.

An increase in the calcium carbonate deposition rate at Broken Ridge occurred between the Santonian and the early Maestrichtian ( $\approx 86$ and $\approx 76$ Ma; Rea et al., 1990; Davies, Luyendyk, et al., 1974). The increase in carbonate deposition is roughly coincident with the opening of the Indian Ocean $(\approx 84 \mathrm{Ma}$; Mutter et al., 1985) and may mark the initiation of open ocean circulation. The carbonate deposition rates $\left(\approx 5 \mathrm{~g} / \mathrm{cm}^{2} / 1000 \mathrm{yr}\right)$; Rea et al., 1990) are extremely high for mid-ocean conditions. The uplifted portions of the southeastern Kerguelen-Heard Plateau could have further increased the carbonate-accumulation rates observed at Broken Ridge by enhancing the upwelling of nutrient-rich waters (Rea et al., 1990).

3. Subsidence of the southeastern Kerguelen-Heard Plateau increased the submerged area available for productivity. The biogenic sediment prograded farther into the basin as a result of the increase in productivity ("3," Fig. 9).

Sequence II was deposited while depths were increasing on Broken Ridge (Figs. 2 and 3; Peirce, Weissel, et al., 1989). The seismic-reflection and drilling data indicate that clinoforms, consisting of carbonate sediments, were prograding north toward the basin during a long-term relative sea-level rise (Figs. 4-7). It is important to note that shorter period eustatic sea-level cycles (i.e., 2d- and 3d-order cycles of Haq, 1987) are superposed on this long-term relative sea-level rise at Broken Ridge. The higher order eustatic sea-level cycles could account for the subtle shifts of downlap observed within Sequence II (Fig. 6). However, the overall stratal pattern is one of continued progradation in response to the long-term relative sea-level rise (Figs. 4-7).

4. Rifting of the Broken Ridge/Kerguelen-Heard Plateau platform began approximately in the middle Eocene (47-50 Ma) based on Leg 121 drilling results ("4," Fig. 9; Peirce, Weissel, et al., 1989). Broken Ridge was uplifted to at least wave base and eroded. The eroded material onlaps Sequence II along the northern slope (Figs. 4, 5, and 7).

A dramatic decrease in depths occurred between the deposition of the youngest sediment below the middle Eocene unconformity and the oldest sediment deposited above the unconformity (Fig. 3 ). The existence of reworked gravels and sands with fragments of bryozoans and mollusks overlying the prominent angular un- 


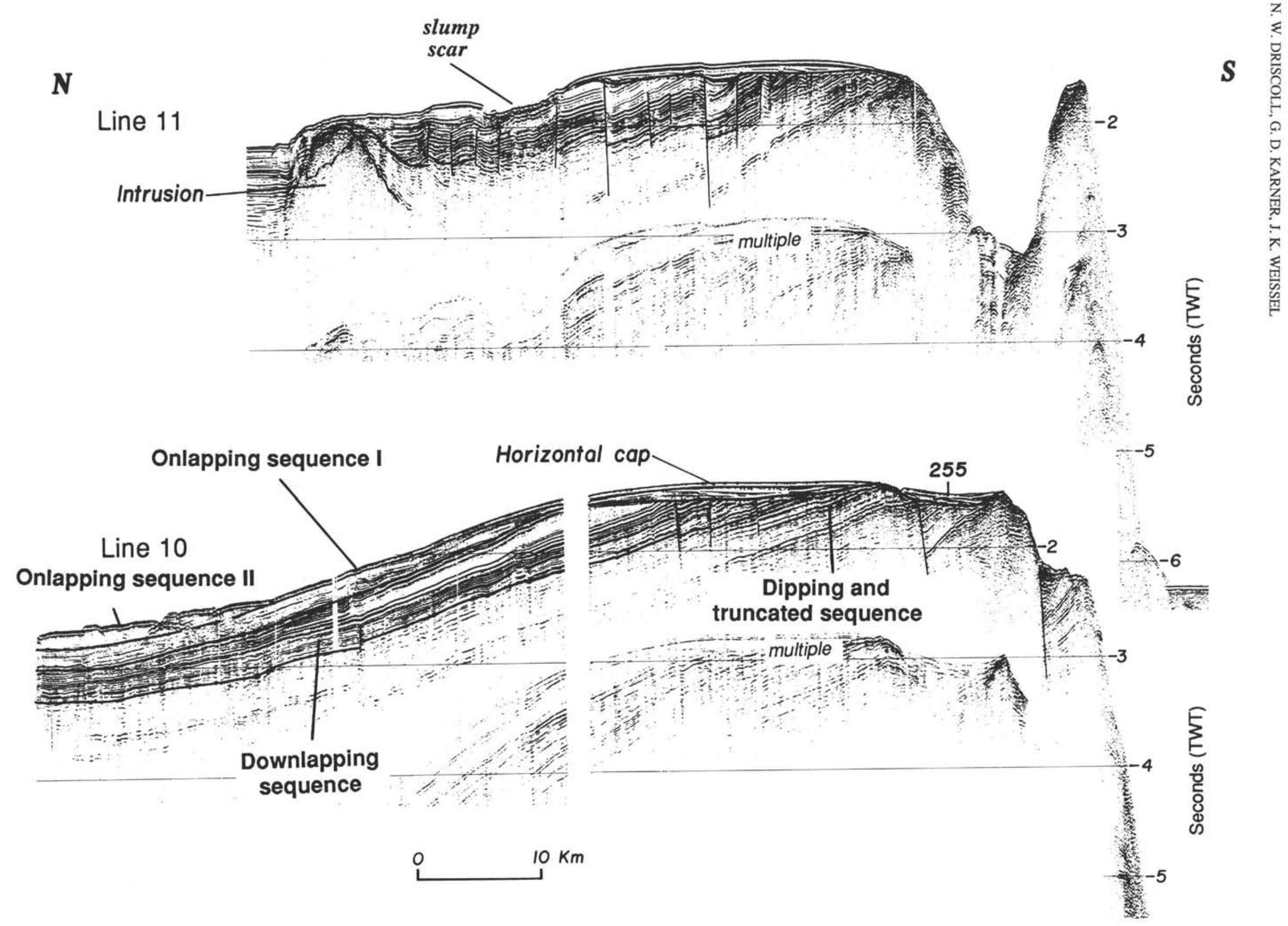




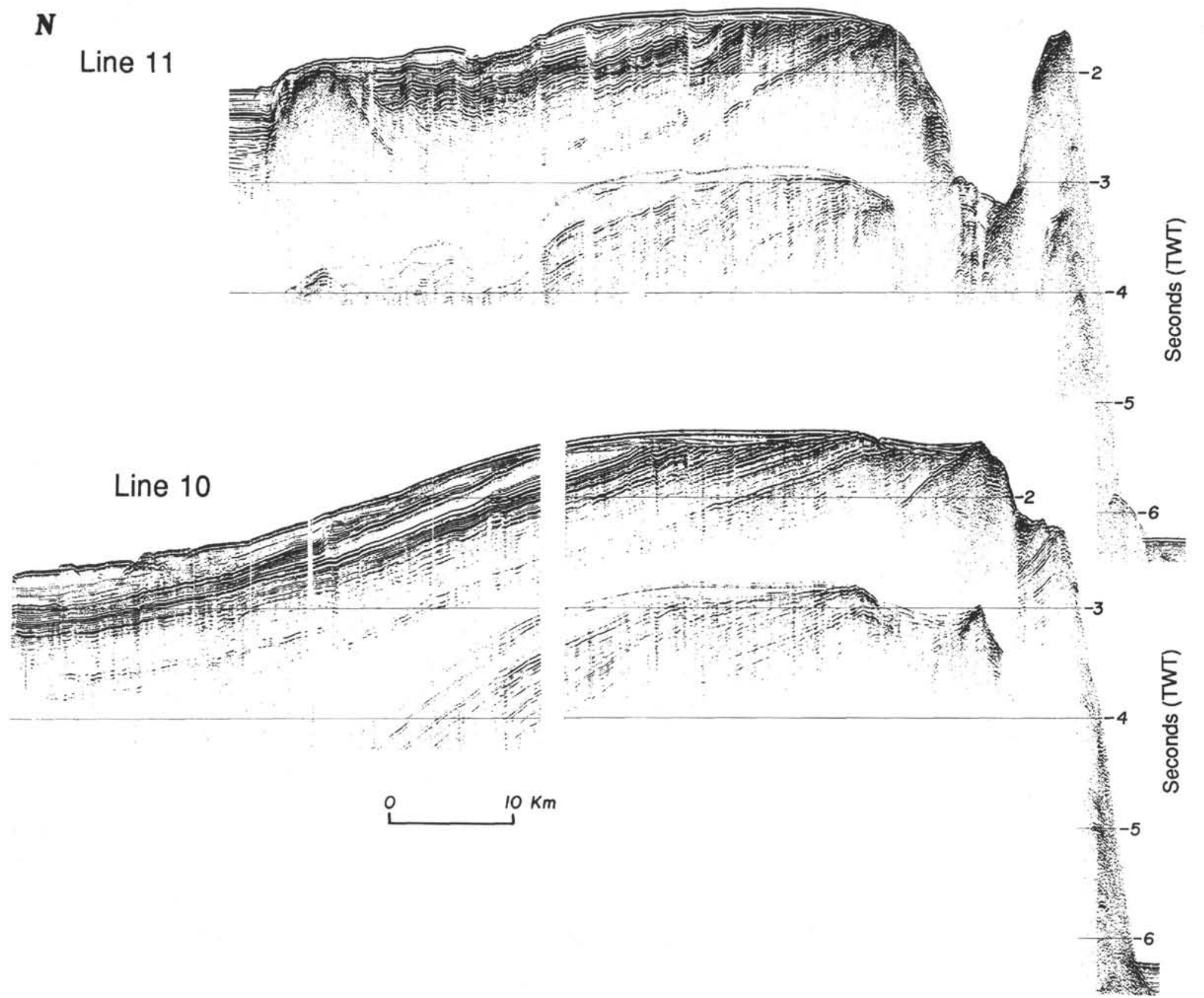




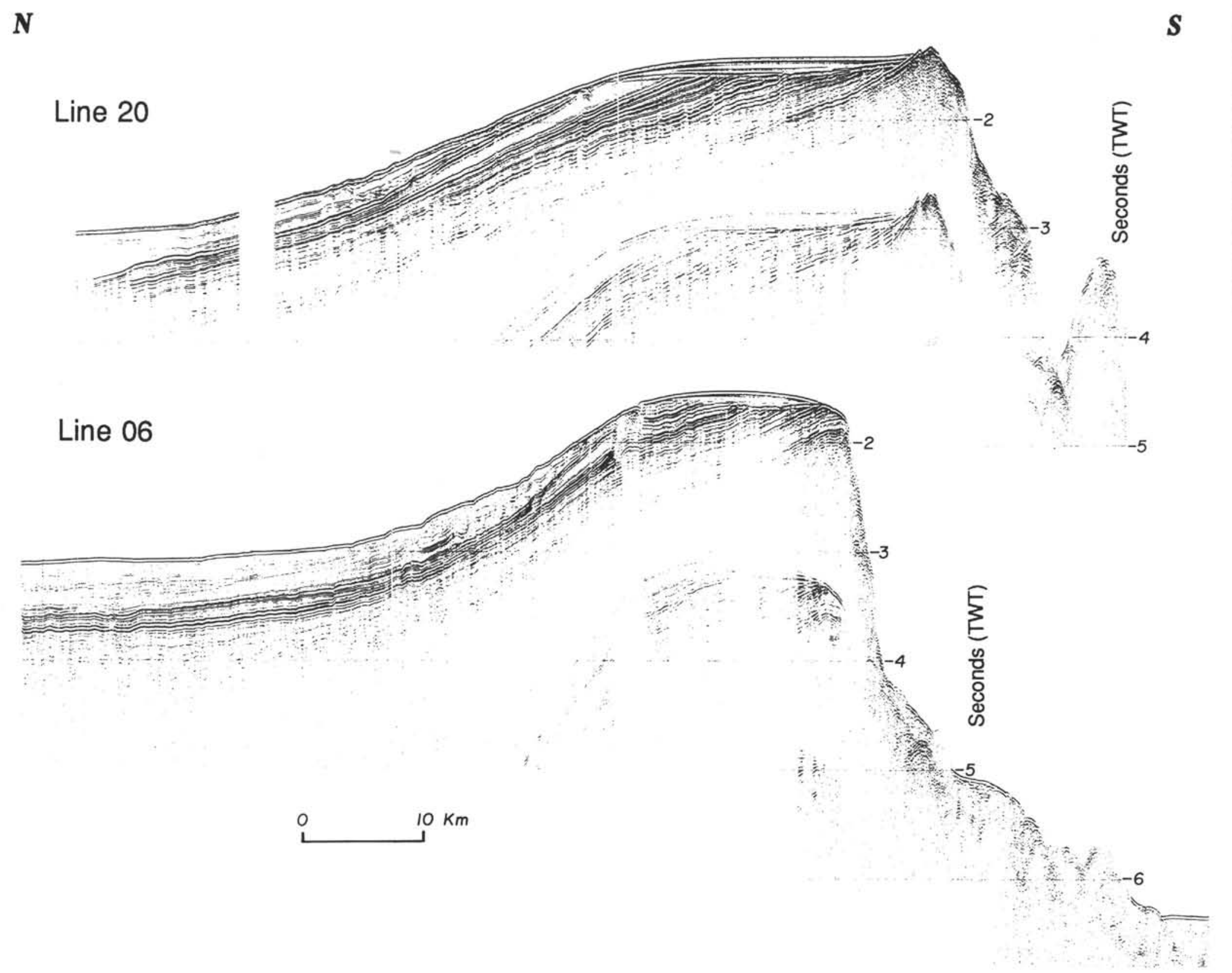




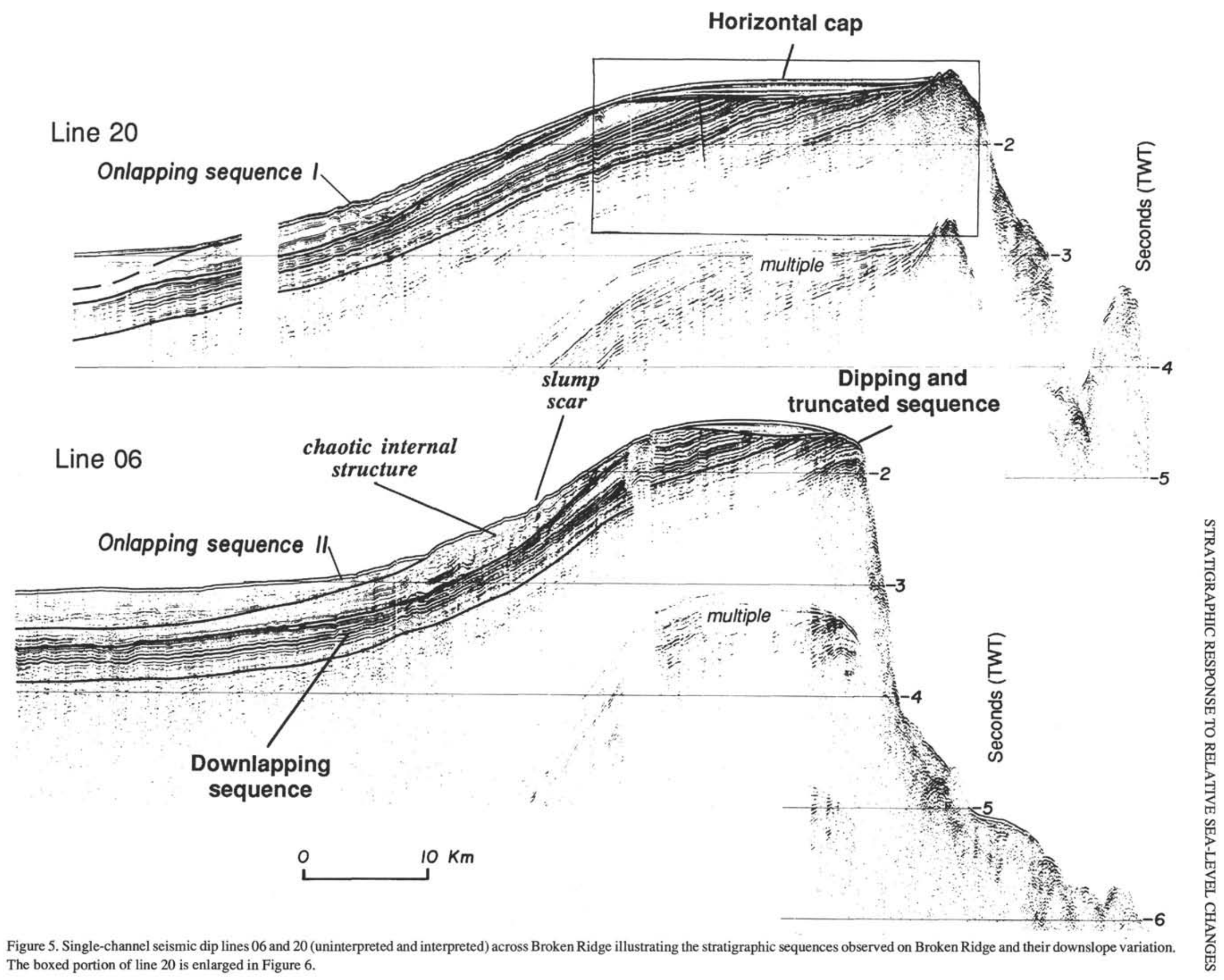


$N$

\section{RC2708 Line 20}

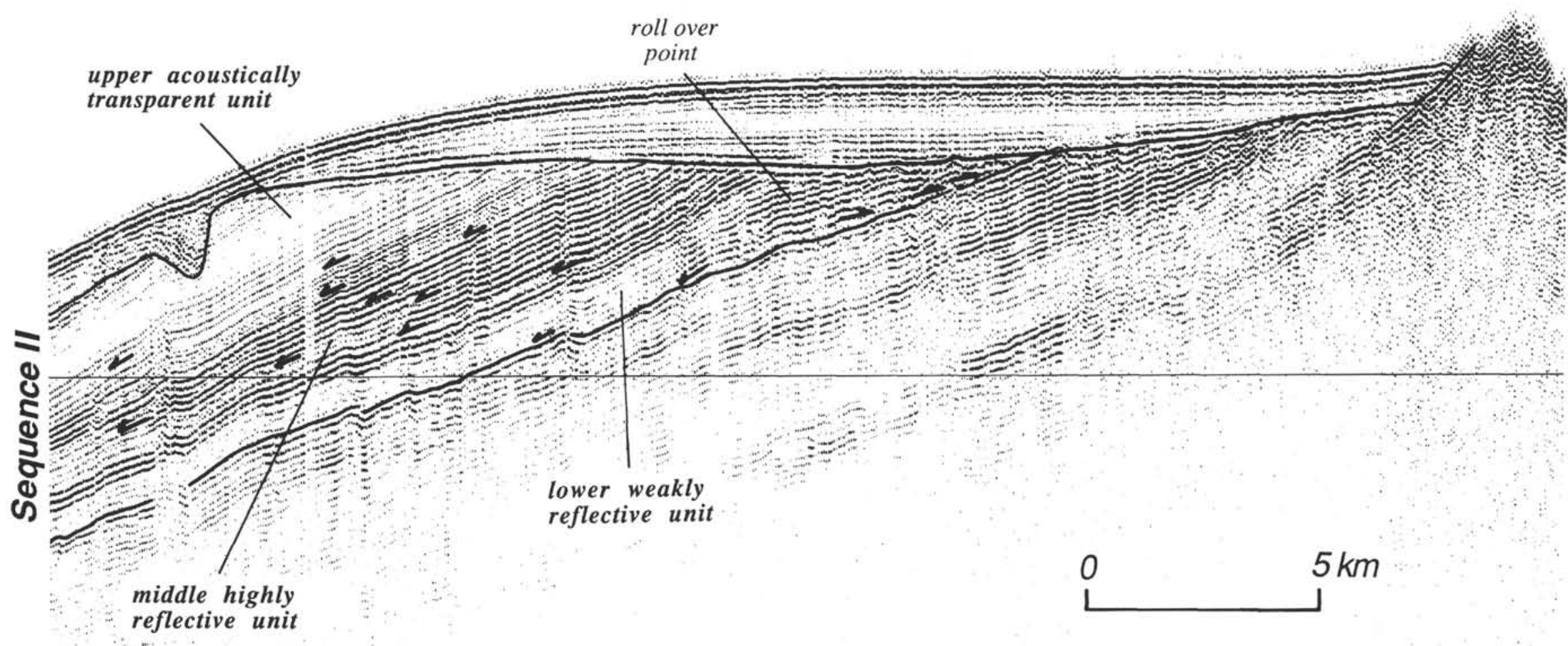

Figure 6. Enlarged portion of line 20, which has been migrated, illustrating the sequence boundary between the dipping and truncated limestones and cherts (Sequence I) and the overlying downlapping sequence (Sequence II). Sequence II consists of three distinct acoustic units: (1) a lower weakly reflective unit, (2) a middle highly reflective unit, and (3) an upper acoustically transparent unit. Note the subtle change of dip in the lower weakly reflective unit denoted by the rollover point. 
conformity in conjunction with the benthic foraminiferal data suggests that Broken Ridge was uplifted at least to wave base. The data suggest that the deposition of Sequence O-I occurred during a relative sea-level fall.

Karst topography is not observed in the seismic-reflection profiles, as might be expected for a relative sea-level fall (Fig. 6). Sites 752, 753, and 754 sampled calcareous chalk below the angular unconformity and there are no signs of increased dissolution and/or cementation (diagenetic front) near the unconformity that diminish with depth beneath the unconformity. The volume estimates for the onlapping sequences (Sequences O-I and O-II) and for the sediment eroded from the crest of Broken Ridge are in close agreement (Fig. 8), also suggesting that little sediment was removed from the system by chemical erosion during the relative sea-level fall.

5. Subsequent to the rift-induced uplift, Broken Ridge subsided to its present depth (Fig. 3; Peirce, Weissel, et al., 1989). This allowed for the accumulation of Sequence III, which onlaps the older dipping and truncated strata ("5," Fig. 9). The sediments of Sequence III show signs of winnowing, perhaps by the CircumPolar Antarctic Current (Rea et al., 1990). The winnowing might also explain the observed thinning toward the northern and southern edge of the ridge (Fig. 6).

\section{SUMMARY}

During the relative sea-level rise on Broken Ridge, which commenced in the early Maestrichtian and culminated in the middle Eocene, clinoforms consisting of carbonate sediments (Sequence II) prograded north toward the basin. Mullins et al. (1988) observed a similar phenomenon on the western Florida escarpment, where middle Miocene clinoforms prograded basinward during a long-term sea-level rise. Prograding clinoforms have also been observed on the southwest Florida margin (Brooks and Holmes, 1989) and Great Bahama Bank (Eberli and Ginsburg, 1987). In all of these examples, the important similarity is that carbonate sediment is deposited from suspension along a concentration gradient, moving from regions of high suspended-sediment concentration to regions of lower concentration. Therefore, despite the increase in water depth due to the rise in relative sea level, the carbonate sediment progrades into the basin because of the high carbonate productivity. In contrast, at a terrigenous margin the sediment supply to the basin diminishes during a relative sea-level rise because the sediment is trapped within the estuaries as the shoreline backsteps landward (Vail et al., 1977; Vail, 1987).

Therefore, slight modification of the Vail (1987) and Sarg (1988) stratigraphic model for carbonate margins during a relative sea-level rise is necessary (Fig. 10). According to the Vail model, the lowstand wedge occurs during a relative sea-level stillstand (i.e., lowstand) or a slight rise. The estuarine/fluvial facies and coastal plain facies migrate in a seaward direction throughout the deposition of the lowstand wedge (Vail, 1987; Posamentier and Vail, 1988). As the relative sea-level rise increases, the previously exposed surfaces are flooded and the shoreline, estuarine/fluvial facies, and coastal plain facies backstep landward. The transgressive surface (TS; Fig. 10) is defined as the first significant marineflooding surface within this sequence (Van Wagoner et al., 1987; Posamentier and Vail, 1988), and denotes the boundary between the transgressive systems tract (TST; Fig. 10) and the underlying lowstand systems tract (LST; Fig. 10). The TST downlaps onto the transgressive surface. The landward shift of downlap within the TST and the development of a condensed section are critically dependent on sediment supply (Posamentier and Vail, 1988).

The increase in sediment supply, as a carbonate ramp is submerged, allows the carbonate sediment to prograde into the basin even though the shoreline, estuarine/fluvial facies, and coastal plain facies backstep landward during deposition of the TST. The resulting stratal patterns (i.e., continued progradation during the deposition of the TST) make it extremely difficult to identify the transgressive surface separating the LST from the overlying TST (Fig. 10). The high carbonate productivity during a relative sealevel rise modifies the observed stratal patterns within the TST. However, these modifications do not invalidate the Vail (1987) and Sarg (1988) model because these authors specified that the landward shift of downlap during a relative sea-level rise and the development of a condensed section are critically dependent on sediment supply (Vail, 1987; Posamentier and Vail, 1988).

During the middle Eocene relative sea-level fall at Broken Ridge, preexisting strata were gently tilted toward the north and truncated. The eroded material was then transported northward toward the basin, onlapping the preexisting strata. The approximate volume balance between the sediment eroded from the crest of Broken Ridge and the sediment deposited at the base of the slope (Sequences O-I and O-II) demonstrates that mechanical erosion and transportation of carbonate sediment into the deep sea were important processes controlling the stratigraphy on Broken Ridge during the relative sea-level fall. The development of Sequence O-I during a relative sea-level fall is in agreement with the Vail (1987) model.

In summary, clastic debris eroded from Broken Ridge behaves according to the terrigenous clastic model (Vail, 1987). Biogenic carbonate production during a relative sea-level rise adds another factor to the Vail model (i.e., increased sediment supply during the rise). The increased sediment supply during the sea-level rise allows carbonate sediment to prograde basinward despite the fact that water depths are increasing. Therefore, we conclude that the stratigraphic response of Broken Ridge during the rift-induced relative sea-level fall is consistent with the stratigraphic predictions of the Vail (1987) and Sarg (1988) model. However, slight modifications of the model are necessary to account for the increase in sediment supply during a relative sea-level rise and, thus, better predict the development of prograding carbonate sediment.

\section{ACKNOWLEDGMENTS}

We thank the captains and crews of R/V Conrad and D/V JOIDES Resolution for their assistance in making this project a success. N. Breen, W. Pitman, H. Posamentier, J. Austin, J. Peirce, and an anonymous reviewer critically reviewed the manuscript and their comments are appreciated. The site survey of Broken Ridge (1986) and major support for this work was by U.S. National Science Foundation grant OCE 85-16918, USSAC/JOI through TAMRF P.O. \#20248, \#20258, and \#20239, and a grant from the ARCO Oil and Gas Company.

Lamont-Doherty Geological Observatory contribution no. 4782 .

\section{REFERENCES}

Brooks, G. R., and Holmes, C. W., 1989. Recent carbonate slope sediments and sedimentary processes bordering a non-rimmed platform: southwest Florida continental margin. In Crevello, P. D., Wilson, J. L., Sarg, J. F., and Read, J. F. (Eds.), Controls on Carbonate Platform and Basin Development. Spec. Publ. Soc. Econ. Paleontol. Mineral., 44:259-272.

Davies, T. A., Luyendyk, B. P., et al., 1974. Init. Repts., DSDP, 26: Washington (U.S. Govt. Printing Office).

Driscoll, N. W., Karner, G. D., Weissel, J. K., and Shipboard Scientific Party, 1989. Stratigraphic and tectonic evolution of Broken Ridge from seismic stratigraphy and Leg 121 drilling. In Peirce, J., Weissel, J., et al., Proc. ODP, Init. Repts., 121: College Station, TX (Ocean Drilling Program), 71-91.

Eberli, G., and Ginsburg, R., 1987. Aggrading and prograding infill of buried Cenozoic seaways, northwestern Great Bahama Bank. In Bally, 
A. W. (Ed.), Atlas of Seismic Stratigraphy. AAPG Stud. Geol., 27(2):97-103.

Haq, B. U., Hardenbol, J., and Vail, P. R., 1987. Chronology of fluctuating sea levels since the Triassic. Science, 235:1156-1167.

Hine, A. C., Wilber, R. J., Bane, J. M., Neumann, A. C., and Lorenson, K. R., 1981. Offbank transport of carbonate sands along open, leeward bank margins: northern Bahamas. Mar. Geol., 42:327-348.

Kendall, C.G.St.C., and Schlager, W., 1981. Carbonates and relative changes in sea level. Mar. Geol., 44:181-212.

Kent, D. V., and Gradstein, F. M., 1985. A Cretaceous and Jurassic geochronology. Geol. Soc. Am. Bull., 96:1419-1427.

Morgan, W. J., 1981. Hotspot tracks and the opening of the Atlantic and Indian oceans. In Emiliani, C. (Ed.), The Sea (vol. 7): New York (Wiley), 443-487.

Mullins, H. T., 1983. Comment on "Eustatic control of turbidites and winnowed turbidites." Geology, 11:57-58.

Mullins, H. T., Gradulski, A. F., Hine, A. C., Melillo, A. J., Wise, S. W., Jr., and Applegate, J., 1988. Three-dimensional sedimentary framework of the carbonate ramp slope of central west Florida: a sequential seismic stratigraphic perspective. Geol. Soc. Am. Bull., 100:514-533.

Mutter, J. C., Hegarty, K. A., Cande, S. C., and Weissel, J. K., 1985. Breakup between Australia and Antarctica: a brief review in the light of new data. Tectonophysics, 114:255-279.

Nafe, J. E., and Drake, C. L., 1957. Variation with depth in shallow and deep water marine sediments of porosity, density and the velocities of compressional and shear waves. Geophysics, 20:523-547.

Neumann, A. C., and Land, L. S., 1975. Lime mud deposition and calcareous algae in the Bight of Abaco, Bahamas: a budget. J. Sediment. Petrol., 45:763-786.

Peirce, J., Weissel, J., et al., 1989. Proc. ODP, Init. Repts., 121: College Station, TX (Ocean Drilling Program).

Posamentier, H., Jervey, M. T., and Vail, P. R., 1988. Eustatic control on clastic deposition. I: conceptual framework. In Wilgus, C. K., Hastings, B. S., Kendall, C. G., Posamentier, H. W., Ross, C. A., and Van
Wagoner, J. C. (Eds.), Sea-level Changes: An Integrated Approach. Spec. Publ. Soc. Econ. Paleontol. Mineral., 42:109-124.

Rea, D. K., Dehn, J., Driscoll, N., Farrell, J., Janecek, T., Owen, R. M., Pospichal, J. L., Resiwati, P., and the ODP Leg 121 Scientific Party, 1990. Paleoceanography of the Eastern Indian Ocean from ODP Leg 121 Drilling on Broken Ridge. Geol. Soc. Am. Bull., 102:679-690.

Sarg, J. F., 1988. Carbonate sequence stratigraphy. In Wilgus, C. K. Hastings, B. S., Kendall, C. G., Posamentier, H. W., Ross, C. A., and Van Wagoner, J. C. (Eds.), Sea-Level Changes: An Integrated Approach. Spec. Publ. Soc. Econ. Paleontol. Mineral., 42:155-181.

Schlager, W., 1988. Carbonate platforms, sequence stratigraphy, and sea level. Assoc. Round Table AAPG Spec. Publ., 1522. (Abstract)

Schlich, R., Wise, S. W., Jr., et al., 1989. Proc. ODP, Init Repts., 120: College Station, TX (Ocean Drilling Program).

Snyder, J. P., 1926. Map Projections Used by the U.S. Geological Survey. U.S. Geol. Survey Bull.

Vail, P. R., 1987. Seismic stratigraphy interpretation utilizing sequence stratigraphy. In Bally, A. W. (Ed.), Atlas of Seismic Stratigraphy. AAPG Stud. Geol., 27(1):1-10.

Vail, P. R., Mitchum, R. M., Jr., Todd, R. G., Widmier, J. M., Thompson, S., III, Sangree, J. B., Bubb, J. N., and Hatelid, W. G., 1977. Seismic stratigraphy and global changes in sea level. In Payton, C. E. (Ed.), Seismic Stratigraphy-Applications to Hydrocarbon Exploration: AAPG. Mem., 26:49-212.

Van Wagoner, J. C., Mitchum, R. M., Jr., Posamentier, H. W., and Vail, P. R., 1987. Key definitions of sequence stratigraphy. In Bally, A. W. (Ed.), Atlas of Seismic Stratigraphy. AAPG Stud. Geol., 27(1):11-14.

Weissel, J. K., and Karner, G. D., 1989. Flexural uplift of rift flanks due to mechanical unloading of the lithosphere during extension. J. Geophys. Res., 94:13919-13950.

Date of initial receipt: 7 March 1990

Date of acceptance: 15 October 1990

Ms 121B-178 
[Blank page] 
N

Line 21

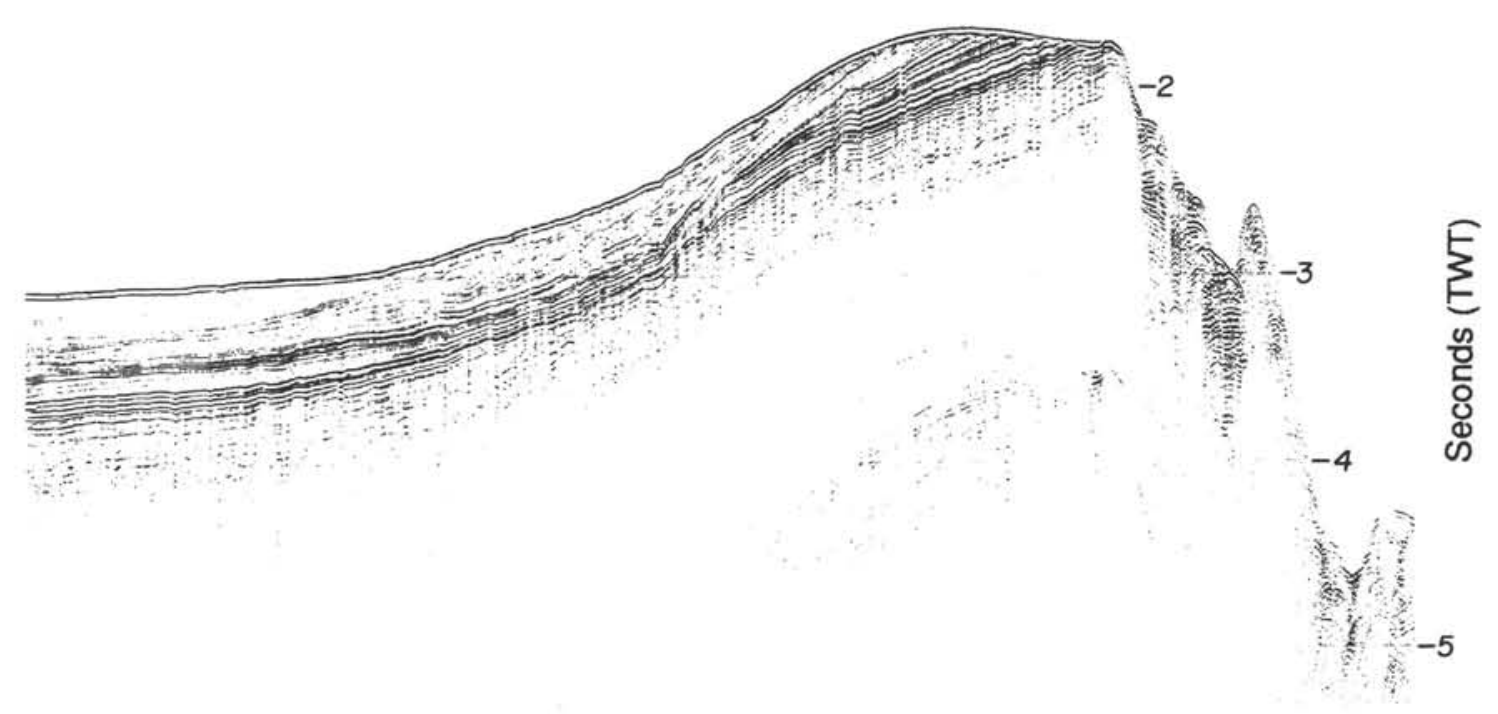

Line 22

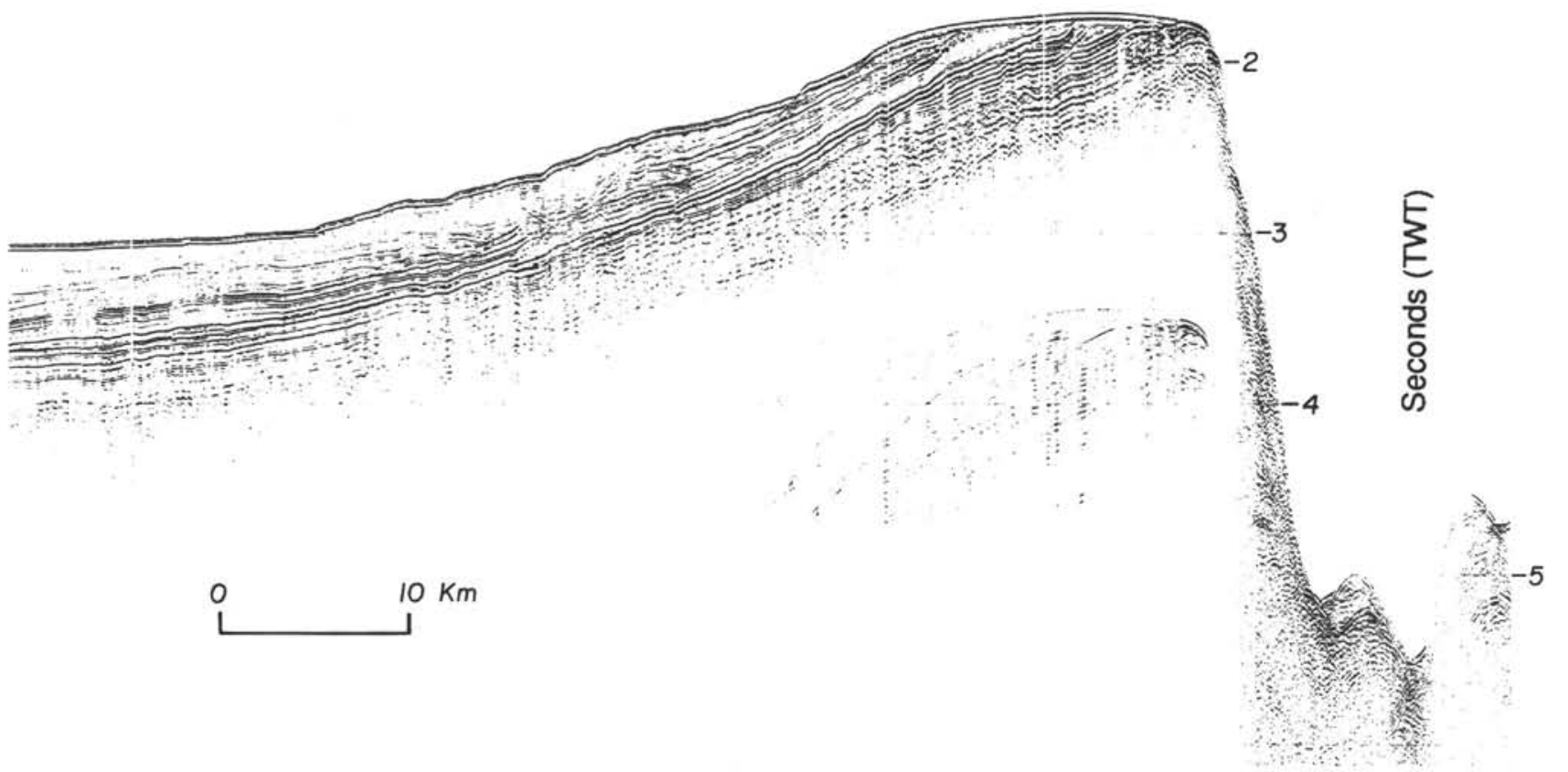


chaotic internal

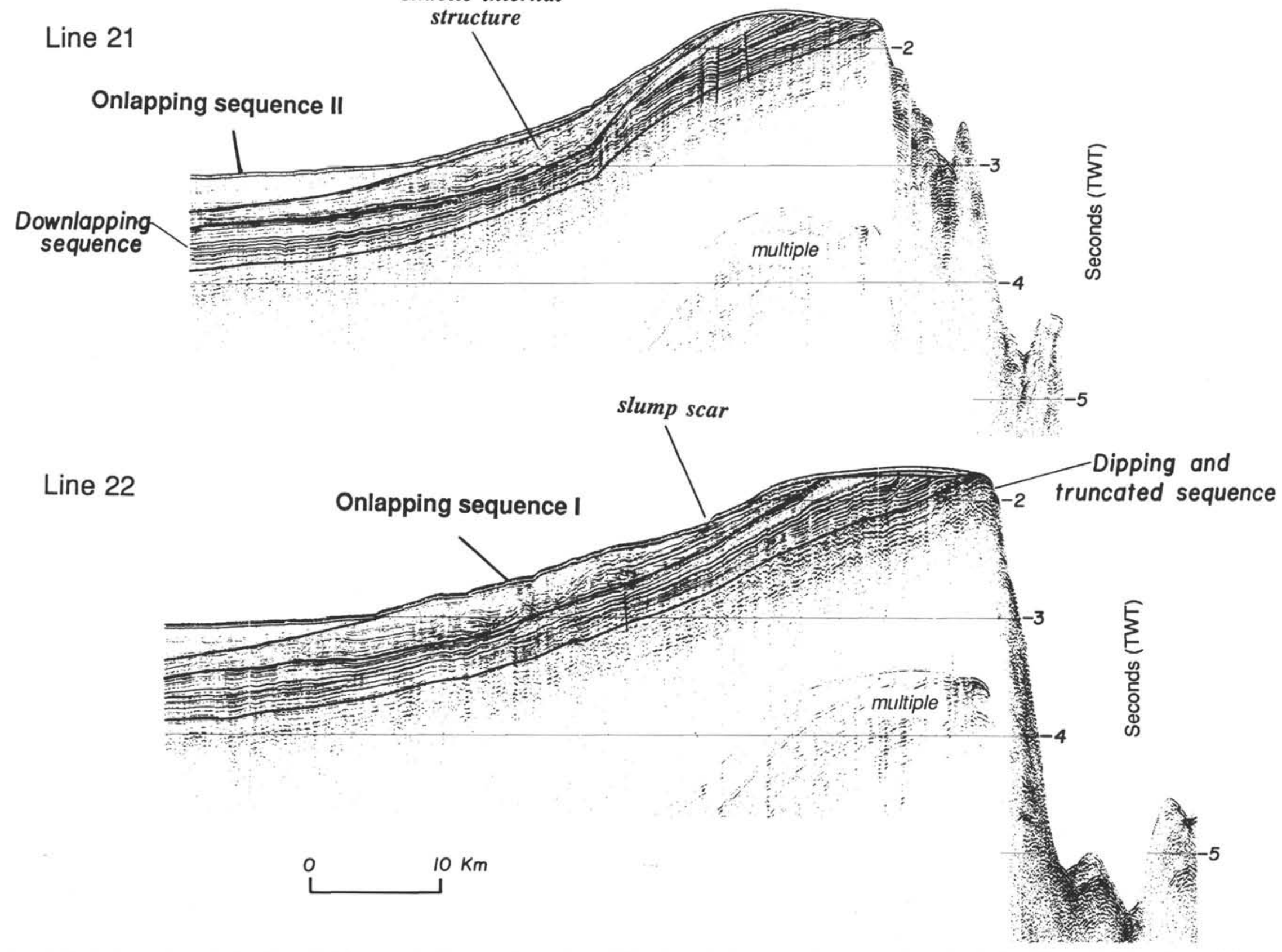




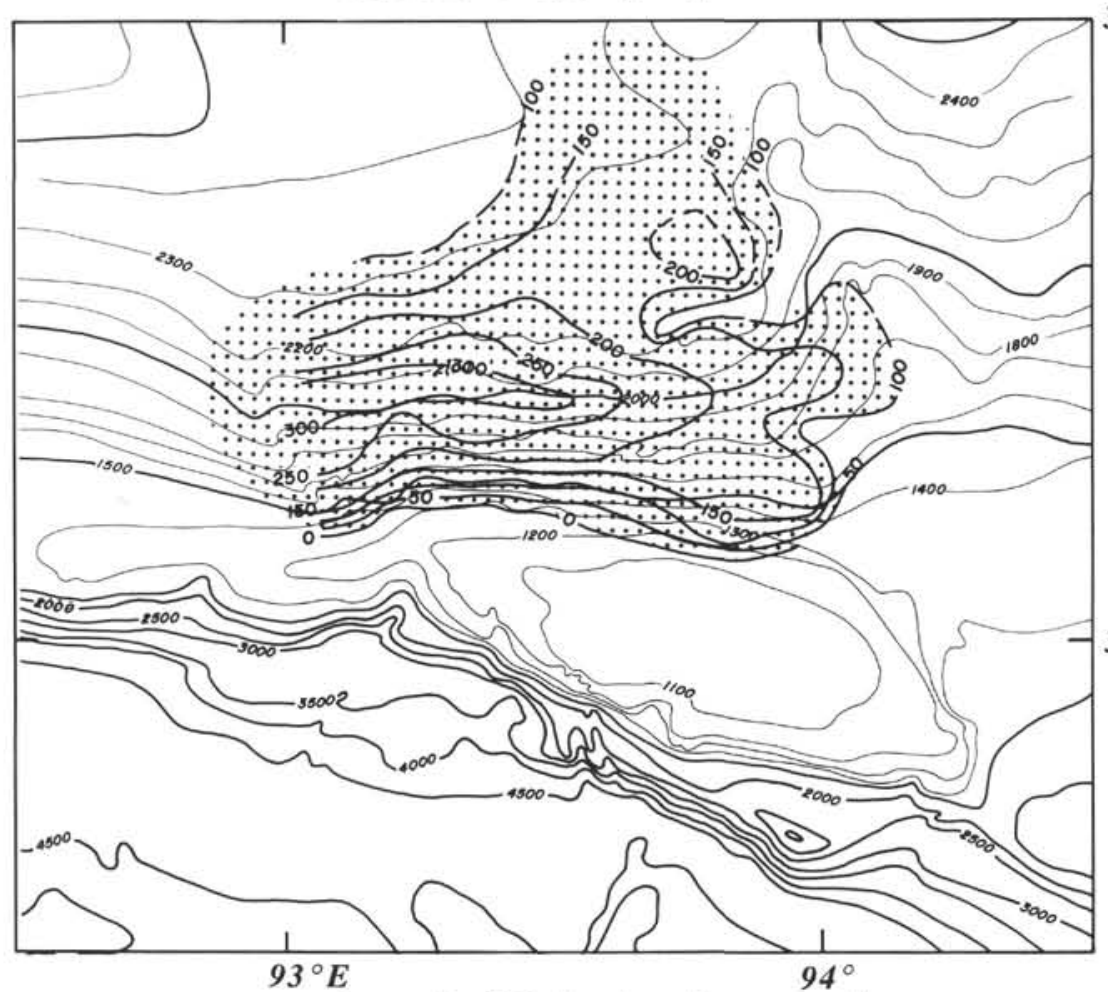

B

Isopach of Onlapping Sequence II

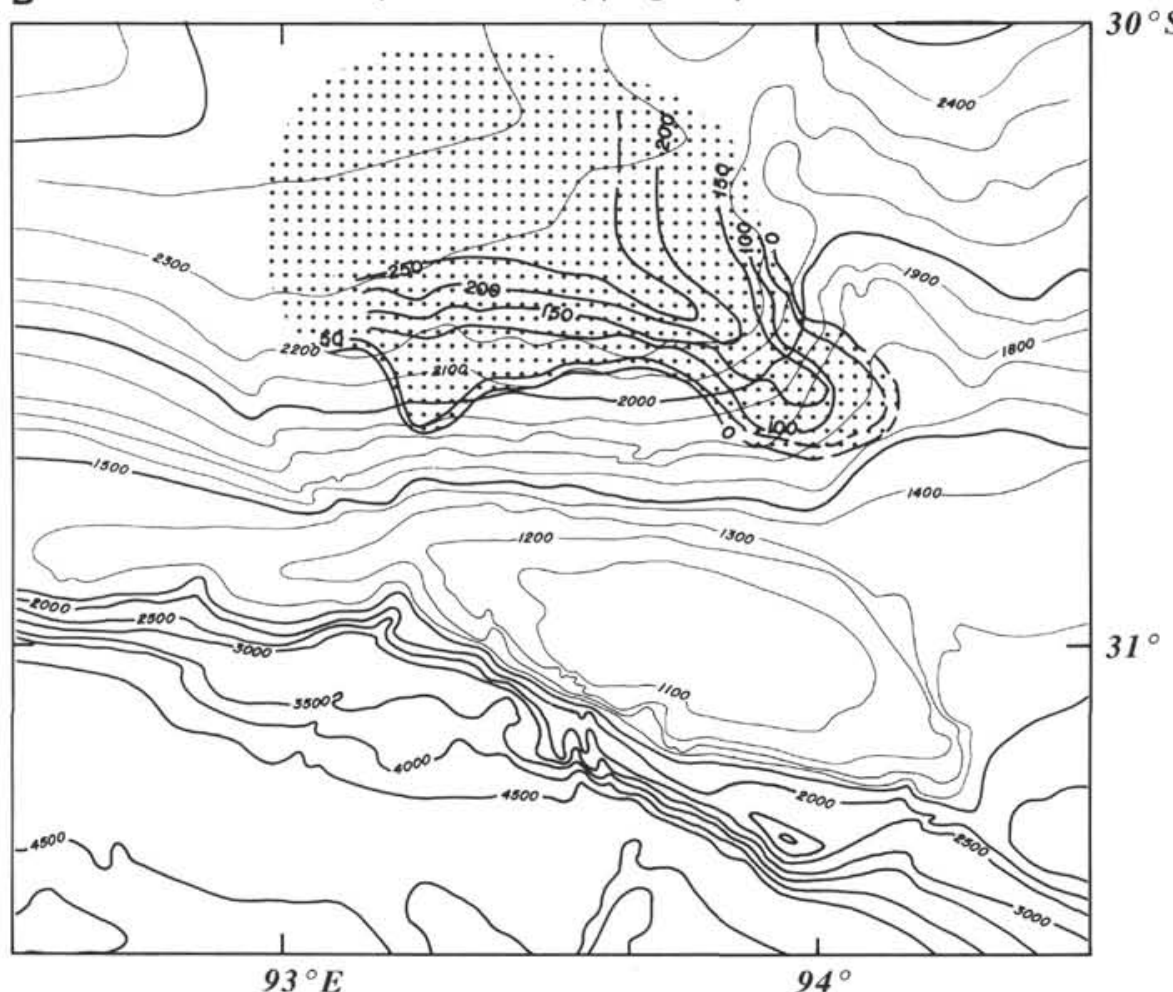

Figure 8. In A-C, the dot pattern highlights isopach and structure contour overlays on the Broken Ridge bathymetry. The contour interval is in meters. A. Isopach map of Sequence O-I. B. Isopach map of Sequence O-II. C. Structure contour map to the base of the horizontal cap (Sequence III). D. Seismic profile collected across Broken Ridge. The dashed line estimates the area of sediment eroded from Broken Ridge during the middle Eocene rifting event. The volume estimates for the onlapping sequences and the eroded material from the crest of Broken Ridge are approximately equal, suggesting that small amounts of sediment were lost from the system by chemical erosion. 
C Depth to Angular Unconformity

D

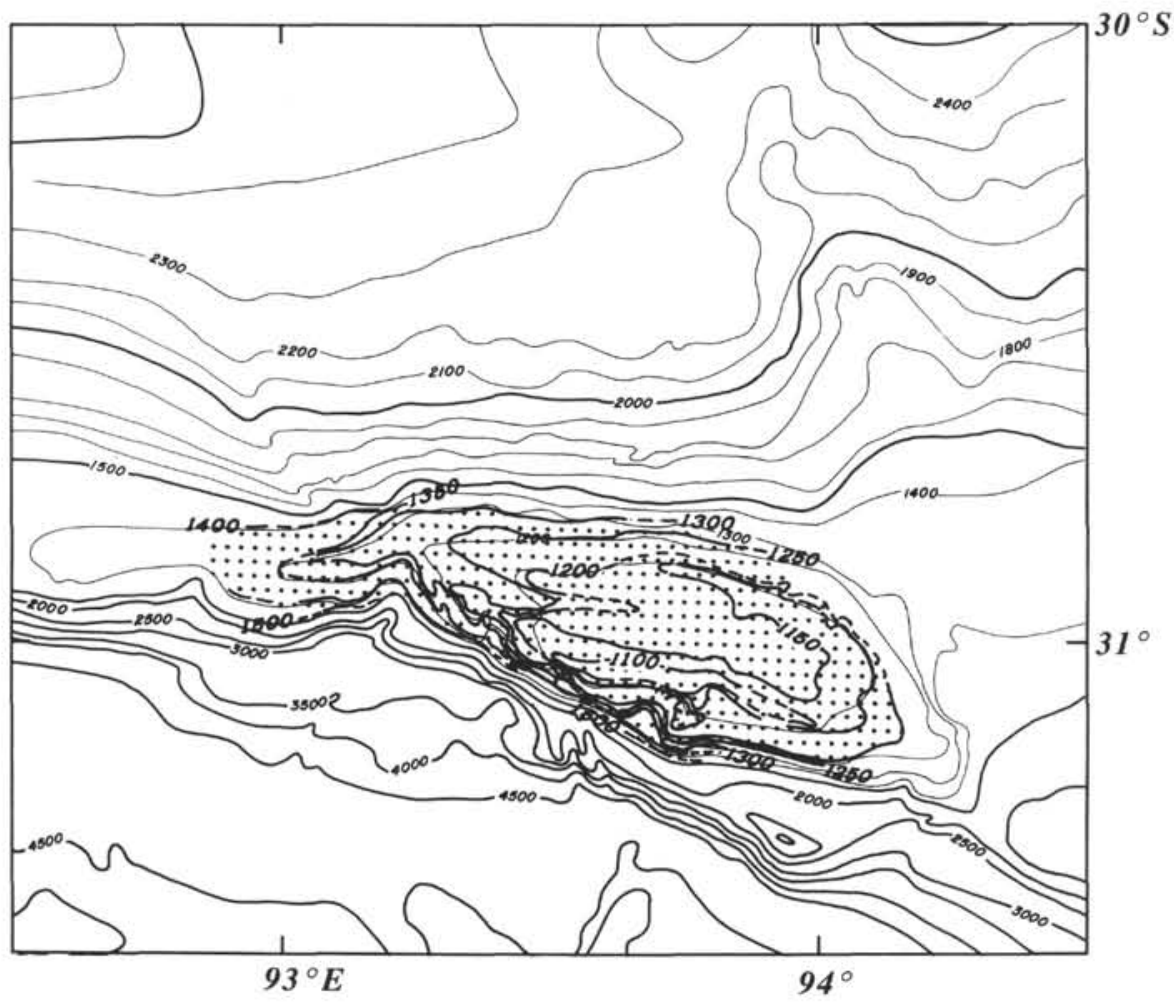

N

$S$

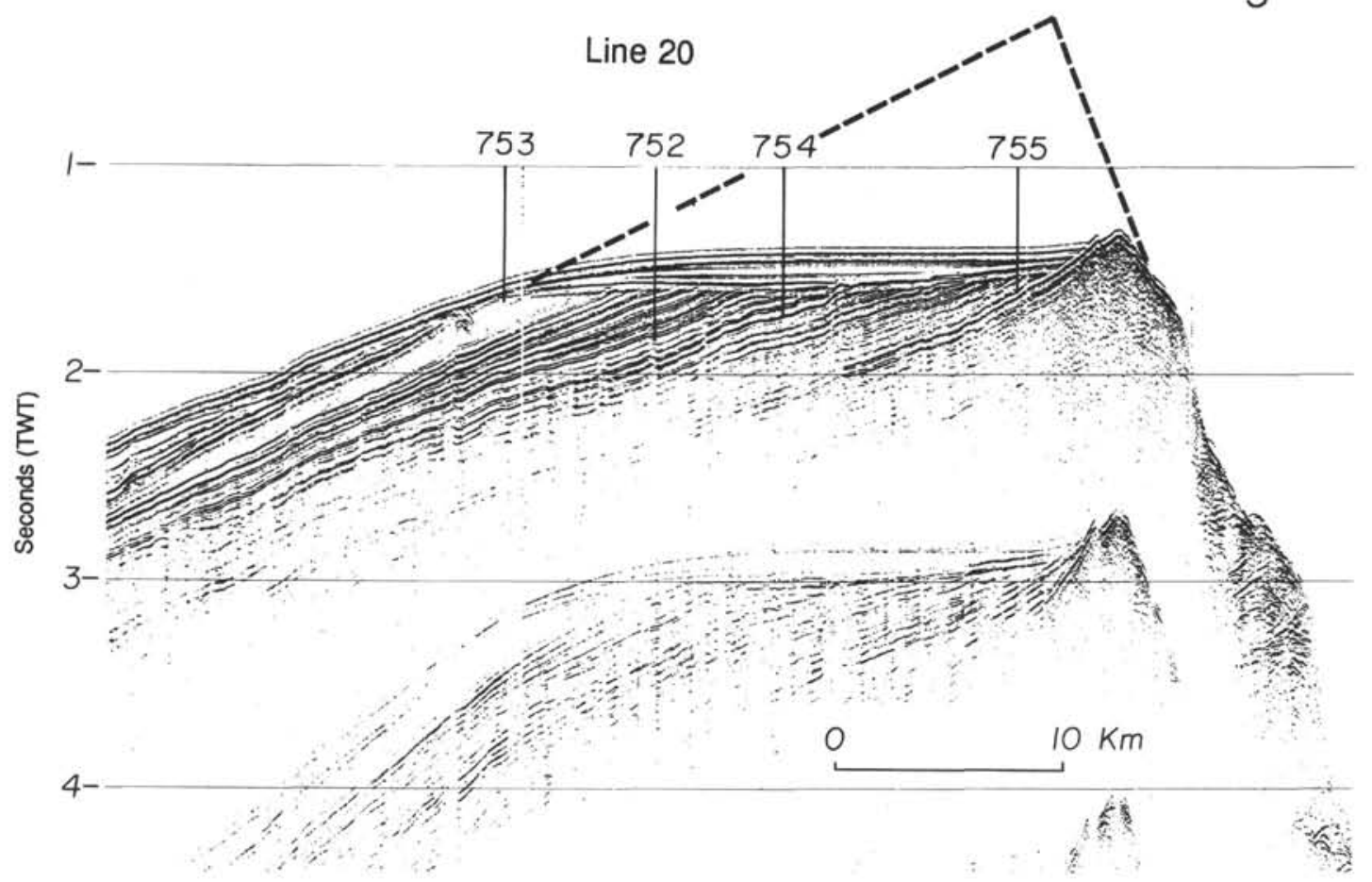

Figure 8 (continued). 
N. W. DRISCOLL, G. D. KARNER, J. K. WEISSEL

$\mathbb{N}$

(1)

Santonian

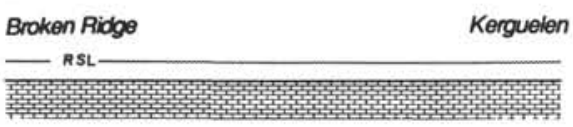

(2)

Maastrichtian

Broken Ridge

Kerguelen

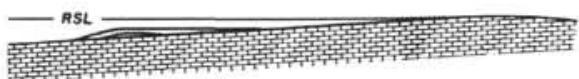

(3)

middle Eocene

$\infty$ Broken Ridge Kerguelen $\infty$

Prograding

downlapping wedge
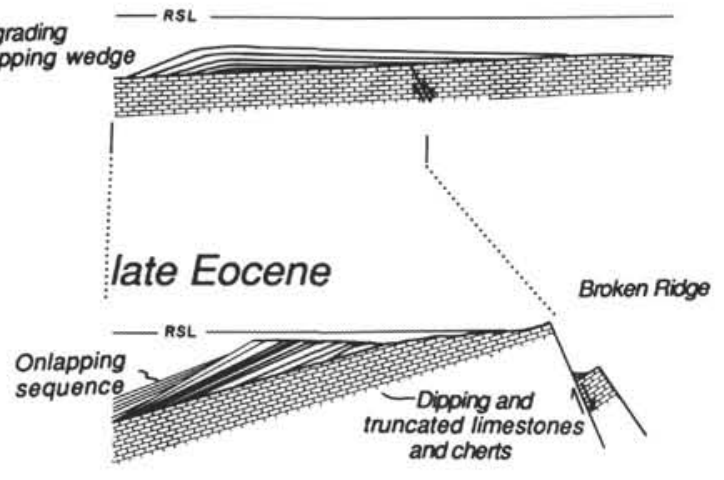

(5)

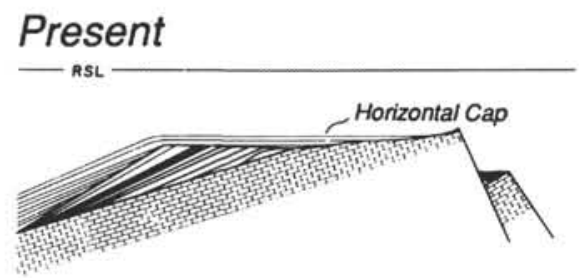

Figure 9. Stratigraphic model for the evolution of Broken Ridge from the Santonian to the present (1-5), illustrating the effects of relative sea-level changes on the resulting stratigraphy. 


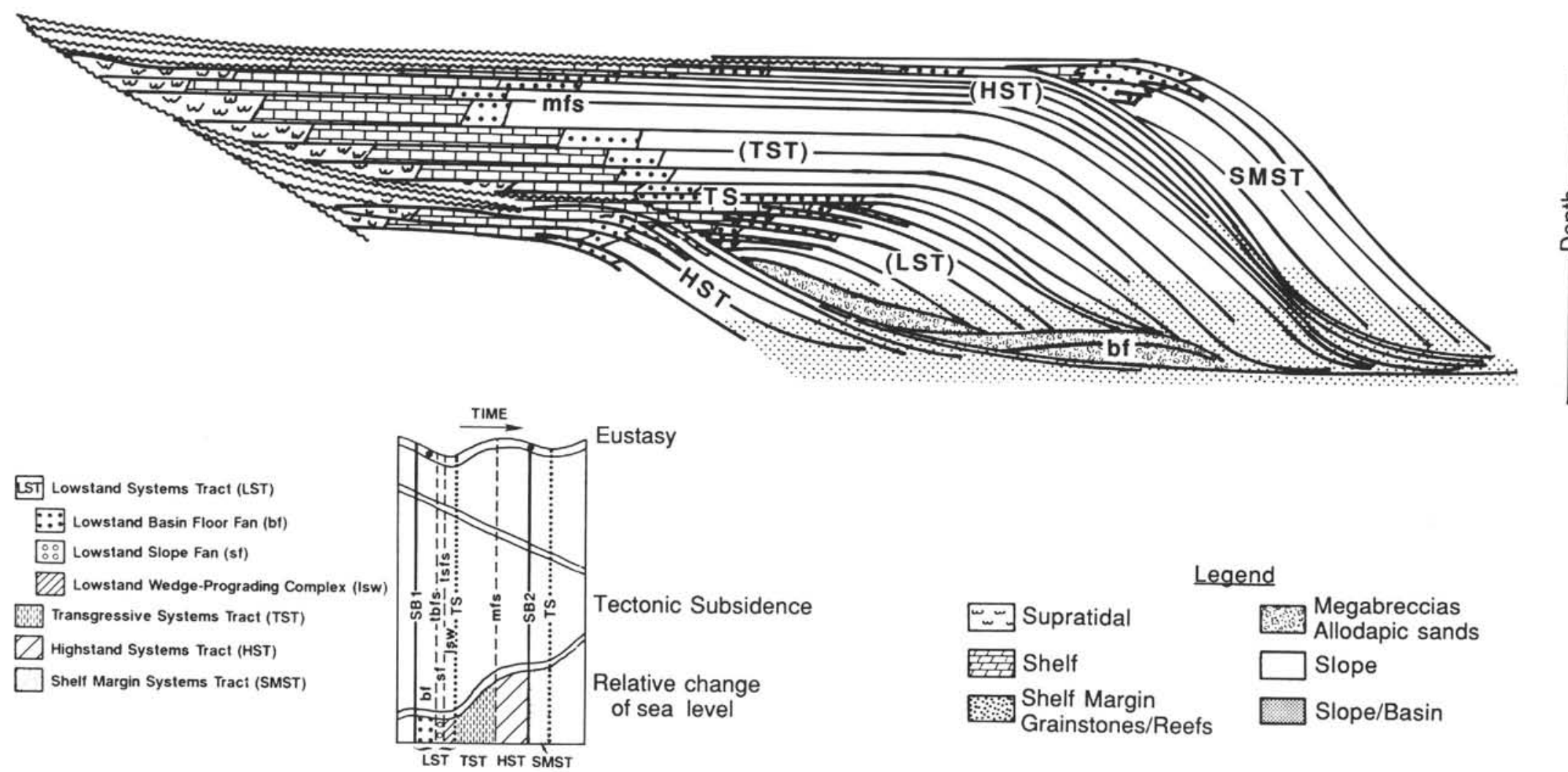

Figure 10. Modified version of the Vail (1987) stratigraphic model for carbonate environments. The major modification is that the transgressive system tract (TST) continues to prograde basinward despite the fact that the shoreline and associated facies may backstep landward. The legend indicates the facies types for the model. 